\title{
Usability Testing Study
}

National Cancer Institute

\section{Source}

National Cancer Institute. Usability Testing Study. NCI Thesaurus. Code C161479.

A type of study designed to evaluate the user experience with a product. 